\title{
THE EFFECT OF POTASSIUM IN NEPHRECTOMIZED RATS WITH HYPOKALEMIC ALKALOSIS
}

\author{
BY JACK ORLOFF, THOMAS J. KENNEDY, JR., AND ROBERT W. BERLINER
}

(From the Laboratory of Kidney and Electrolyte Metabolism, National Heart Institute, National

Institutes of Health, United States Public Health Service, Federal Security Agency, Bethesda 14, Maryland)

(Submitted for publication February 5, 1953; accepted March 5, 1953)

On the basis of balance studies conducted on rats recovering from hypokalemic alkalosis, Cooke, Segar, Cheek, Coville and Darrow (1) have concluded that a shift of hydrogen ions into muscle cells in exchange for potassium is the basis of the extracellular alkalosis. This thesis received further support from the studies of Black and Milne (2) on the development of hypokalemic alkalosis in man.

Since the contribution of acid and alkaline residues from the diet is dependent upon the metabolic state of the animal, the precise interpretation of balance data in chronic experiments is rendered difficult. Consequently, the acute effect of the administration of potassium to nephrectomized rats with hypokalemic alkalosis has been studied. In this way it is possible to examine more critically whether exchanges of ions across cell membranes in the absence of the kidneys can account for alterations in the bicarbonate content of the extracellular fluid.

\section{METHODS}

Fifty-three male rats of the Sprague-Dawley strain, weighing approximately 250 grams, were made hypokalemic and alkalotic by removing potassium from their diets and administering $2 \mathrm{mg}$. of desoxycorticosterone acetate daily subcutaneously for a period of seven days. During this time their drinking water was a solution containing 0.25 per cent sodium chloride and 0.25 per cent sodium bicarbonate. On the day of the experiment the rats were divided into three approximately equal groups. The first group, represented in the tables as untreated rats, were anesthetized with $12 \mathrm{mg}$. of nembutal administered intravenously. Blood for analysis was withdrawn from the abdominal aorta into heparinized syringes. Approximately 15 grams of muscle was dissected free from the hind limbs. This was freed of all visible fat, tendon, and nerve and immediately prepared for analysis. Bilateral nephrectomies were performed on the remaining rats under ether anesthesia, care being taken not to remove the adrenals. Upon recovery from anesthesia, each rat in the potassium treated group was given a solution containing $2 \mathrm{mEq}$. of potassium ${ }^{1}$ intravenously over a period of approximately three hours. The remaining rats received an equal amount of a solution of the same anion content but with sodium substituted for the potassium. Upon completion of the infusion all of the rats were handled in the same manner as were the untreated animals.

Arterial blood $\mathrm{pH}$ was measured at room temperature in a Beckman Model $\mathrm{G} \mathrm{pH}$ meter and corrected to 39 degrees by substracting .014 unit per degree centigrade. The total carbon dioxide of the plasma was determined by the method of Van Slyke and Neill (3). Sodium and potassium in diluted plasma and in a diluted extract of the muscle were measured by internal standard flame photometry. Chloride in plasma and muscle was determined by the iodometric titration of Van Slyke and Hiller (4). The muscle samples were prepared for analysis by diluting with distilled water, homogenizing in a Waring blendor and boiling for 30 minutes in a sealed tube. The supernatant was then removed and analyzed. This method is a modification of the extraction method of Heilbrunn (5) for the determination of chloride and has been validated for sodium, potassium, and chloride by Cotlove (6).

The muscle data are presented as mEq. per $\mathrm{Kg}$. of whole muscle, and differ from data obtained on fat free extracts of muscle by approximately 1 per cent (7). Total water in muscle was assumed to be $760 \mathrm{ml}$. per $\mathrm{Kg}$. Although this may not be accurate under all of the conditions of these experiments, the error introduced by such an assumption will not affect the conclusions. The extracellular space was calculated as the volume of distribution of chloride. All other calculations were done in the usual manner. The concentrations of sodium and chloride in extracellular water were calculated from their respective plasma concentrations taking into account the Gibbs-Donnan effect and the water content of plasma.

\section{RESULTS}

The mean values and the standard errors of the means of the original and derived data are presented in Table I. The significance of differences between groups for the various quantities deter-

1 Given $13.3 \mathrm{ml}$. of a solution containing $126 \mathrm{mM}$ of potassium chloride and $24 \mathrm{mM}$ of potassium bicarbonate per liter. 
mined is presented in Table II. It can be seen that the untreated rats, sacrificed without infusion of either sodium or potassium salts, were alkalotic and hypokalemic. The administration of $2 \mathrm{mEq}$. of potassium to such alkalotic animals resulted in a marked fall in plasma bicarbonate and $\mathrm{pH}$, and a rise in plasma potassium. This marked alteration in the extracellular electrolyte pattern is to be compared with the lesser, although significant, changes effected by the intravenous injection of 2 $\mathrm{mM}$ of sodium salts. It can be calculated that the addition of $13.3 \mathrm{ml}$. of such a solution containing a lower concentration of bicarbonate than is originally present in the plasma will depress the bicarbonate concentration approximately 1 to 2 $\mathrm{mEq}$. per $\mathrm{L}$. This dilution effect accounts for some of the change noted here. Further depression of the bicarbonate concentration is presumably due to the nephrectomy since a fall in plasma bicarbonate was found three hours following nephrectomy in untreated rats. These effects together are of sufficient magnitude to account for all of the fall in plasma bicarbonate in the sodiumtreated group.
The concentrations of sodium and potassium in the muscle of untreated rats were distinctly abnormal, there being $31 \mathrm{mEq}$. of sodium per $\mathrm{Kg}$. of intracellular water as compared with the normal of 10 ; and $125 \mathrm{mEq}$. of potassium per $\mathrm{Kg}$. of intracellular water as compared with the normal of 160 (7). Approximately three potassium ions had been replaced by two sodium ions in the development of the alkalosis, corresponding to the ratio reported by others $(8,9)$. The muscle electrolyte content was unaffected by the injection of $2 \mathrm{mEq}$. of sodium, supporting the view that the alterations in plasma electrolyte pattern noted in the sodiumtreated rats were not due to exchanges of ions between the intracellular and extracellular compartments.

In striking contrast to the effect of sodium, the administration of $2 \mathrm{mEq}$. of potassium tended to reverse the abnormal muscle electrolyte pattern with an average uptake of $17 \mathrm{mEq}$. of potassium per $\mathrm{Kg}$. of intracellular water in exchange for 15 $\mathrm{mEq}$. of sodium. Presumably the difference between potassium uptake and sodium extrusion represents a relative loss of hydrogen ion to the

TABLE I

Plasma and muscle electrolytes in hypokalemic alkalotic rats

\begin{tabular}{|c|c|c|c|c|c|c|c|c|c|c|}
\hline & & \multicolumn{4}{|c|}{ Plasma } & \multicolumn{5}{|c|}{ Muscle } \\
\hline & & $\mathrm{Na}^{+}$ & $\mathrm{K}^{+}$ & $\mathrm{Cl}^{-}$ & $\overline{\mathrm{HCO}_{3}^{-}}$ & $\mathrm{Na}^{+}$ & $\mathrm{K}^{+}$ & $\mathrm{Cl}^{-}$ & $\mathrm{Na}^{+}$ & $\mathrm{K}^{+}$ \\
\hline Group & $\mathrm{pH}$ & $m E q . / L$ & $m E q . / L$. & $m E q . / L$ & $m E q . / L$ & 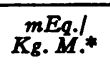 & $\begin{array}{c}m E q . l \\
K_{g .} \cdot M_{.} *\end{array}$ & $\begin{array}{c}m E_{q .} / \\
K_{g} \cdot M \cdot *\end{array}$ & $\begin{array}{c}m E_{g . I} \\
K_{g . I . \dagger}\end{array}$ & $\begin{array}{l}m E q .1 \\
K_{g .} I . \dagger\end{array}$ \\
\hline
\end{tabular}

Untreated

\begin{tabular}{lrrrrrrrrrrr}
\hline Mean & 7.55 & 139.6 & 2.14 & 100.9 & 32.3 & 36.9 & 79.8 & 13.7 & 30.9 & 125.3 \\
N & 16 & 17 & 17 & 17 & 17 & 16 & 16 & 16 & 16 & 16 \\
S.E. & 0.008 & 0.88 & 0.074 & 0.74 & 0.50 & 0.79 & 0.89 & 0.26 & 1.29 & 1.55 \\
\hline
\end{tabular}

Nephrectomized $\mathrm{K}^{+}$treated

\begin{tabular}{lrrrrrrrrrr}
\hline Mean & 7.46 & 137.8 & 3.90 & 106.8 & 23.4 & 28.2 & 93.4 & 15.3 & 15.9 & 142.2 \\
N & 19 & 19 & 19 & 19 & 19 & 18 & 18 & 18 & 18 & 18 \\
S.E. & 0.018 & 0.87 & 0.18 & 0.86 & 0.64 & 0.65 & 1.14 & 0.31 & 1.16 & 4.30 \\
\hline
\end{tabular}

Nephrectomized $\mathrm{Na}^{+}$treated

\begin{tabular}{|c|c|c|c|c|c|c|c|c|c|c|}
\hline $\begin{array}{l}\text { Mean } \\
\text { N.E. }\end{array}$ & $\begin{array}{c}7.51 \\
17 \\
0.013\end{array}$ & $\begin{array}{r}142.1 \\
17 \\
0.87\end{array}$ & $\begin{array}{r}2.20 \\
17 \\
0.13\end{array}$ & $\begin{array}{r}104.3 \\
17 \\
0.50\end{array}$ & $\begin{array}{r}27.5 \\
17 \\
0.41\end{array}$ & $\begin{array}{c}39.8 \\
16 \\
0.77\end{array}$ & $\begin{array}{r}80.3 \\
16 \\
1.25\end{array}$ & $\begin{array}{r}15.4 \\
16 \\
0.31\end{array}$ & $\begin{array}{r}32.6 \\
16 \\
1.43\end{array}$ & $\begin{array}{r}129.0 \\
16 \\
2.16\end{array}$ \\
\hline
\end{tabular}

N Refers to the number of observations.

S.E. Refers to the standard error of the mean.

* mEq. per kilogram of whole muscle.

$\dagger \mathrm{mEq}$. per kilogram of intracellular water. 
TABLE II

Probability of difference between means arising by chance

\begin{tabular}{|c|c|c|c|c|c|c|c|c|}
\hline \multirow[b]{2}{*}{ Groups } & \multirow[b]{2}{*}{$\mathrm{pH}$} & \multicolumn{4}{|c|}{ Plasma } & \multicolumn{3}{|c|}{ Muscle } \\
\hline & & $\mathrm{Na}^{+}$ & $\mathrm{K}^{+}$ & $\mathrm{Cl}^{-}$ & $\mathrm{HCO}_{3}-$ & $\begin{array}{l}\text { Whole } \\
\text { muscle } \\
\mathrm{Cl}^{-}\end{array}$ & $\begin{array}{l}\text { Intra- } \\
\text { cellular } \\
\mathrm{Na}^{+}\end{array}$ & $\begin{array}{c}\text { Intra- } \\
\text { cellular } \\
\mathrm{K}^{+}\end{array}$ \\
\hline$\overline{\mathrm{X}}_{1}$ vs. $\overline{\mathrm{X}}_{2}$ & $<.001$ & $\sim .5$ & $<.001$ & $<.001$ & $<.001$ & $<.001$ & $<.001$ & $<.001$ \\
\hline $\bar{X}_{1}$ vs. $\bar{X}_{3}$ & $<.01$ & .06 & $>.5$ & $<.001$ & $<.001$ & $<.001$ & 0.4 & 0.2 \\
\hline$\overline{\mathrm{X}}_{2}$ vs. $\overline{\mathrm{X}}_{3}$ & .03 & $<.001$ & $<.001$ & $<.02$ & $<.001$ & $>.5$ & $<.001$ & $<.01$ \\
\hline
\end{tabular}

$\overline{\mathrm{X}}_{1}=$ Mean of untreated group.

$\bar{X}_{2}=$ Mean of potassium-treated group.

$\overline{\mathrm{X}}_{\mathbf{3}}=$ Mean of sodium-treated group.

extracellular fluid. ${ }^{2}$ The titration of extracellular bicarbonate by this hydrogen ion accounts for the reduction in plasma $\mathrm{pH}$ and bicarbonate. The ratio of the amounts of sodium and potassium exchanged in the recovery from the alkalosis in these experiments is different from that noted in the development of alkalosis. This may be due to the brevity of the experiments and to the absence of renal regulations. Despite this, the estimated $2 \mathrm{mEq}$. of hydrogen ion per $\mathrm{Kg}$. of intracellular water released into the extracellular space is, within the errors of the analyses, of sufficient magnitude to account for the observed reduction in plasma bicarbonate.

\section{DISCUSSION}

It is apparent from these studies that the disappearance of hypokalemic alkalosis when potassium salts are administered is not due to any activity of the kidneys. This is in accord with the findings in balance studies of Cooke and associates (1). If the sequence of events in the development of the alkalosis is the reverse of that transpiring in its disappearance, then the kidneys do not play an essential role in the development of the alkalosis other than to effect the loss of the potassium from the body. The data of Black and Milne support this contention (2). Obviously then, the hypoth-

2 It is recognized that the final electrolyte distribution will be the same whether this is viewed as an exchange of intracellular hydrogen ion for extracellular potassium or as an uptake of potassium bicarbonate. The uptake of any other anion with potassium would increase the concentration of plasma bicarbonate. If the cation exchange mechanism is considered as operative, the potassium taken up in exchange for hydrogen ion must end up distributed between the fixed buffer anions of the cell and bicarbonate, the concentration of which has increased (10). esis attributing the alkalosis to a net loss of acid from the body is incorrect (11). The alkalosis is apparently confined to the extracellular compartment and is associated with intracellular acidosis brought about by a transfer of hydrogen ions into cells in exchange for potassium.

It is in the maintenance of the extracellular alkalosis that the kidneys assume the principal role. In hypokalemic alkalosis the final urine contains less bicarbonate than one would expect from the magnitude of the bicarbonate concentration in the glomerular filtrate (12) were the kidneys responding in a normal fashion. This must be due to an increase in the rate of secretion of hydrogen ions since the bicarbonate content of the final urine is dependent upon the interaction between filtered bicarbonate and secreted acid. The increase in hydrogen ion secretion in potassium depletion is in accord with the observation that there is an inverse relationship between the urinary secretion of these ions under a variety of circumstances (11, 13). It has been suggested that this inverse relationship is due to competition between hydrogen and potassium ions for secretion by the renal tubules (11). If the cells of the renal tubules engage in the same exchanges with the extracellular fluids as do the muscle cells, then in hypokalemic alkalosis the tubule cells are also more acid than normal. The increased concentration of hydrogen ions within the renal cells would tend to favor the secretion of acid and accounts for the diminished excretion of bicarbonate relative to filtered load. A return to the normal relationship between plasma bicarbonate and bicarbonate excretion is attendant upon the administration of potassium which presumably enters the tubule cells and displaces hydrogen into the extracellular fluids. 
Although there is evidence of competition between hydrogen and potassium for secretion by the renal tubules, the precise nature of this competition is not clear. In hypokalemic alkalosis the tubule cells presumably contain less potassium and more hydrogen than normal; the rate of secretion of these ions is also inversely related. There is no way of determining with certainty whether the urinary findings are due to the reciprocal changes in the concentration of these ions in the cells with the rate of secretion of each directly related to its intracellular concentration, or whether an increase in the cellular concentration of hydrogen alone or a decrease in the concentration of potassium alone is sufficient to produce these results. Although the acceleration of potassium secretion induced by carbonic anhydrase inhibitors (11) may be due solely to a diminution in the cellular concentration of hydrogen, there is no clearcut evidence that this is so, since the concentration of potassium in the cells may rise as that of hydrogen ion falls. Such an increase in potassium concentration occurring only in the tubule cells affected by carbonic anhydrase inhibitors would be virtually impossible to demonstrate in either tissue analyses or balance experiments.

In contrast, the renal behavior attending respiratory modifications of acid-base balance suggests that a relative preponderance of one ion will depress the secretion of the other by the renal tubule. Despite the high concentration of bicarbonate in the glomerular filtrate in respiratory acidosis, the urine is more acid than would be expected were there a normal relationship between filtered and excreted bicarbonate. There is no evidence that the intracellular concentration of potassium diminishes in muscle cells (14). In view of the free diffusibility of $\mathrm{CO}_{2}$, however, the $\mathrm{pCO}_{2}$ must be elevated in the intracellular as well as the extracellular fluids with a resultant increase in the hydrogen ion concentration of cells. If the tubule cells undergo similar alterations in composition, since the increase is in the concentration of hydrogen ion alone, the behavior of these cells with respect to potassium excretion might give an indication of whether an increase in the concentration of one ion alone is sufficient to depress the excretion of the other. This latter view is supported by the observation that respiratory acidosis in man is associated with an increase in hydrogen ion secretion and a diminution in that of potassium (15). Conversely the low $\mathrm{pCO}_{2}$ of respiratory alkalosis must lower the hydrogen ion concentration within cells. Despite the lack of evidence of potassium uptake by muscle cells (16), acid secretion by the kidney is suppressed and that of potassium enhanced $(17,18)$. While data concerning the electrolyte composition of the cells actually involved in the secretion of potassium and hydrogen ions are not available, present information would appear to support the view that a relative excess or deficit of hydrogen ion is sufficient to effect an inverse change in potassium secretion without a reciprocal change in the concentration of potassium within the cell.

\section{SUM MARY}

Rats were made hypokalemic and alkalotic by feeding them a diet deficient in potassium and by administering desoxycorticosterone acetate. The intravenous infusion of potassium salts after nephrectomy resulted in an uptake of potassium by the muscle cells and a fall in the plasma $\mathrm{pH}$ and bicarbonate concentration. The significance of these results with respect to the pathogenesis and maintenance of hypokalemic alkalosis was discussed.

\section{REFERENCES}

1. Cooke, R. E., Segar, W. E., Cheek, D. B., Coville, F. E., and Darrow, D. C., The extrarenal correction of alkalosis associated with potassium deficiency. J. Clin. Invest., 1952, 31, 798.

2. Black, D. A. K., and Milne, M. D., Experimental potassium depletion in man. Clin. Sc., 1952, 11, 397.

3. Van Slyke, D. D., and Neill, J. M., The determination of gases in blood and other solutions by vacuum extraction and manometric measurement. J. Biol. Chem., 1924, 61, 523.

4. Van Slyke, D. D., and Hiller, A., Application of Sendroy's iodometric chloride titration to protein-containing fluids. J. Biol. Chem., 1947, 167, 107.

5. Heilbrunn, L. V., and Hamilton, P. G., The presence of chloride in muscle fibres. Physiol. Zool., 1942, 15, 363.

6. Cotlove, E., Unpublished observations.

7. Cotlove, E., Holliday, M. A., Schwartz, R., and Wallace, W. M., Effects of electrolyte depletion and acid-base disturbance on muscle cation. Am. J. Physiol., 1951, 167, 665.

8. Heppel, L. A., The electrolytes of muscle and liver in potassium depleted rats. Am. J. Physiol., 1939, 127, 385. 
9. Darrow, D. C., Schwartz, R., Iannucci, J. F., and Coville, F., Relation of serum bicarbonate concentration to muscle composition. J. Clin. Invest., 1948, 27, 198.

10. Gardner, L. I., MacLachlan, E. A., and Berman, H., Effect of potassium deficiency on carbon dioxide, cation, and phosphate content of muscle. J. Gen. Physiol., 1952, 36, 153.

11. Berliner, R. W., Kennedy, T. J., Jr., and Orloff, J., Relationship between acidification of the urine and potassium metabolism. Effect of carbonic anhydrase inhibition on potassium excretion. Am. J. Med., 1951, 11, 274.

12. Kennedy, T. J., Jr., Winkley, J. H., and Dunning, M. F., Gastric alkalosis with hypokalemia. Am. J. Med., 1949, 6, 790.

13. Orloff, J., and Kennedy, T. J., Jr., Effect of lithium on acidification of the urine. Federation Proc., 1952, $11,115$.
14. Cooke, R. E., Coughlin, F. R., Jr., and Segar, W. E., Muscle composition in respiratory acidosis. J. Clin. Invest., 1952, 31, 1006.

15. Elkinton, J. R., Singer, R. B., Barker, E. S., and Clark, J. K., Effects of acute respiratory acidosis on electrolyte excretion in man. Federation Proc., 1953, 12, 38.

16. Darrow, D. C., and Sarason, E. L., Some effects of low atmospheric pressure on rats. J. Clin. Invest., 1944, 23, 11.

17. McCance, R. A., and Widdowson, E. M., The response of the kidney to an alkalosis during salt deficiency. Proc. Roy. Soc., London, (B), 1936, $120,228$.

18. Stanbury, S. W., and Thomson, A. E., The renal response to respiratory alkalosis. Clin. Sc., 1952, 11, 357. 